AperTO - Archivio Istituzionale Open Access dell'Università di Torino

\title{
Microbiological characterization of Gioddu, an Italian fermented milk
}

\section{This is the author's manuscript}

Original Citation:

Availability:

This version is available http://hdl.handle.net/2318/1734830

since 2020-04-02T09:06:03Z

Published version:

DOI:10.1016/j.ijfoodmicro.2020.108610

Terms of use:

Open Access

Anyone can freely access the full text of works made available as "Open Access". Works made available under a Creative Commons license can be used according to the terms and conditions of said license. Use of all other works requires consent of the right holder (author or publisher) if not exempted from copyright protection by the applicable law. 


\section{Journal Pre-proof}

Microbiological characterization of Gioddu, an Italian fermented milk

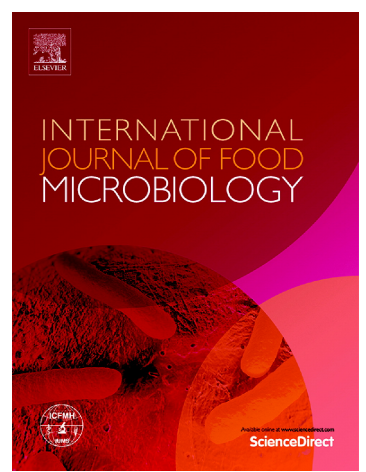

Antonietta Maoloni, Giuseppe Blaiotta, Ilario Ferrocino, Nicoletta P. Mangia, Andrea Osimani, Vesna Milanović, Federica Cardinali, Cristiana Cesaro, Cristiana Garofalo, Francesca Clementi, Marina

Pasquini, Maria Federica Trombetta, Luca Cocolin, Lucia Aquilanti

PII: S0168-1605(20)30104-5

DOI: https://doi.org/10.1016/j.ijfoodmicro.2020.108610

Reference:

FOOD 108610

To appear in: International Journal of Food Microbiology

Received date: $\quad 20$ January 2020

Revised date: $\quad 21$ February 2020

Accepted date: $\quad 19$ March 2020

Please cite this article as: A. Maoloni, G. Blaiotta, I. Ferrocino, et al., Microbiological characterization of Gioddu, an Italian fermented milk, International Journal of Food Microbiology (2018), https://doi.org/10.1016/j.ijfoodmicro.2020.108610

This is a PDF file of an article that has undergone enhancements after acceptance, such as the addition of a cover page and metadata, and formatting for readability, but it is not yet the definitive version of record. This version will undergo additional copyediting, typesetting and review before it is published in its final form, but we are providing this version to give early visibility of the article. Please note that, during the production process, errors may be discovered which could affect the content, and all legal disclaimers that apply to the journal pertain.

(C) 2018 Published by Elsevier. 


\section{Microbiological characterization of Gioddu, an Italian fermented milk}

Antonietta Maoloni ${ }^{1}$, Giuseppe Blaiotta ${ }^{2}$, Ilario Ferrocino ${ }^{3}$, Nicoletta P. Mangia ${ }^{4, *}$, Andrea Osimani ${ }^{1 * *}$, Vesna

Milanović ${ }^{1}$, Federica Cardinali ${ }^{1}$, Cristiana Cesaro ${ }^{1}$, Cristiana Garofalo ${ }^{1}$, Francesca Clementi ${ }^{1}$, Marina Pasquini ${ }^{1}$, Maria Federica Trombetta ${ }^{1}$, Luca Cocolin ${ }^{3}$, Lucia Aquilanti ${ }^{1}$

${ }^{1}$ Dipartimento di Scienze Agrarie, Alimentari ed Ambientali, Università Politecnica delle Marche, via Brecce Bianche, 60131, Ancona, Italy

${ }^{2}$ Dipartimento di Agraria, University of Naples Federico II, Via Università 100, Portici, NA 80055, Italy

${ }^{3}$ Department of Agricultural, Forest, and Food Science, University of Turin, Largo Paolo Braccini 2, 10095, Grugliasco, Torino, Italy

${ }^{4}$ Dipartimento di Agraria, Università degli Studi di Sassari, Viale Italia 39, 07100 Sassari, Italy

\section{Corresponding authors at:}

- Dipartimento di Agraria, Università degli Studi di Sassari, Viale Italia 39, 07100 Sassari, Italy. E-mail address: nmangia@uniss.it (NPM)

- Dipartimento di Scienze Agrarie, Alimentari ed Ambientali, Università Politecnica delle Marche, via Brecce Bianche, 60131, Ancona, Italy. E-mail address: a.osimani@univpm.it (AO) 


\section{Abstract}

Gioddu, also known as "Miciuratu”, “Mezzoraddu”, or "Latte ischidu” (literally meaning acidulous milk), is the sole variety of traditional Italian fermented milk. The aim of the present study was to elucidate the microbiota as well as the mycobiota occurring in artisan Gioddu samples collected from three Sardinian producers by combining the results of viable counting on selective culture media and, high-throughput sequencing. Physico-chemical parameters were also measured. The overall low pH values (3.80-4.22) detected in the analyzed Gioddu samples attested the strong acidifying activity carried out by lactic acid bacteria during fermentation. Viable counts revealed the presence of presumptive lactococci, presumptive lactobacilli, and non-Saccharomyces yeasts. A complex (kefir-like) microbiota of bacteria and yeasts was unveiled through sequencing. In more detail, the dominance of Lactobacillus delbrueckii was highlighted in all the samples, thus representing the key species in Gioddu fermentation together with Streptococcus thermophilus, whose presence suggested the establishment of a yogurt-like protocooperation. Unexpectedly, samples from two out of the three producers revealed the presence of Lactobacillus kefiri in all the three analyzed batches, thus representing an absolute novelty and suggesting the presence of bioactive compounds (e.g. exopolysaccharides) similar with those present in milk kefir beverage. Mycobiota population, studied for the very first time, revealed a more complex population where Kluyveromyces marxianus, Galactomyces candidum and Geotrichum galactomyces constituted the core mycobiota. Further research is needed to disclose the presence in Gioddu of probiotic cultures and bioactive compounds (e.g. exopolysaccharides, angiotensin-converting enzyme inhibitory peptides, antimicrobial compounds) with potential health-benefits for the consumers.

Keywords: yeast-lactic fermentation, metagenomic sequencing, Lactobacillus delbrueckii, Lactobacillus kefiri, Kluyveromyces marxianus. 


\section{Introduction}

Milk represents a perishable food and its fermentation has been from long time one of the main strategies to extend its shelf life. The history of milk fermentation dates to Sumerians, Babylonians, Pharos and Indians although the exact origin of such a practice is difficult to be established (Tamime, 2002). At the present time, fermented milks are produced at both industrial and artisan scale through complex processes that are usually based on a combination of ancient techniques and modern knowledge (biochemistry, enzymology, microbiology, physics and engineering) (Tamime, 2002). The production of fermented milks is obtained by the conversion of lactose in milk to lactic acid using starter cultures obtained from previous manufactures (back-slopping) or by direct inoculum of selected microbial strains. The microorganisms involved in the biochemical modifications of milk include lactic acid bacteria (the main microorganisms involved in the production of lactic acid) or a combination of lactic acid bacteria and eumycetes (generally yeasts) (Aryana and Olson, 2017; Cardinali et al., 2016; 2017). It is noteworthy that many lactic acid bacteria strains produce exopolysaccharides thus enhancing the rheological properties of the fermented milk and improving health benefits to consumers (Rahbar Saadat et al., 2019). Moreover, fermented milk can be a natural source of probiotic microorganisms able to lower risk and therapy support for gastrointestinal diseases, enhance the immune responses and maintain urogenital health although the interaction among probiotics, diet and host is still to be fully clarified (Ceapa et al., 2013).

Based on their physicochemical and microbiological characteristics, fermented milks can be tentatively classified as: i) milk products produced by mesophilic (e.g. cultured buttermilk) or thermophilic (e.g. yogurt) lactic acid fermentation; ii) milk products fermented by lactic acid bacteria and yeasts (e.g. kefir and koumis); milk products fermented by lactic acid bacteria and moulds (Tamime, 2002).

Many fermented dairy products are manufactured all over Italy in accordance with ancient local traditions and are considered by consumers as a heritage of undisputed value. Gioddu, also known as “Miciuratu”, "Mezzoraddu”, or "Latte ischidu” (literally meaning acidulous milk) is an acid-alcoholic fermented beverage produced in Sardinia (Italy) using ovine or goat milk (Maoloni et al., 2019). It is included in the official list of Sardinian traditional products published by the Italian Ministry of Agriculture and Forestry (G.U. Repubblica Italiana no. 168, 22/07/2015 Suppl. Ord. no. 43). The preparation of Gioddu from boiled or pasteurized milk is usually carried out via back-slopping using Gioddu obtained from previous productions. It is characterized by a porcelain white colour with a creamy consistency (firmer than cow's yoghurt) and acidic taste. The typical aroma of Gioddu reflects that of the milk of the species of origin. 
To the authors' knowledge, only a few studies dealing with the characterization of the microbiota occurring in Gioddu have been carried out (Arrizza et al., 1983; Maoloni et al., 2019; Ortu et al., 2007). To date, a few lactic acid bacteria species have been identified together with concurrent yeast species, which have very recently been detected through Polymerase Chain Reaction-Denaturing Gradient Gel Electrophoresis (PCR-DGGE) analysis of the microbial DNA extracted directly from Gioddu samples (Maoloni et al., 2019). Notwithstanding, the microbiology of Gioddu is still far from being disclosed, being such an ancient fermented milk a still unlisted source of microbial diversity. Indeed, the most recent study on Gioddu has been carried out with the exclusive use of a culture-independent technique (PCRDGGE) that, although still useful for the study of complex microbial communities, is characterized by well-known biases that usually allow the detection of the sole dominant species (Cocolin et al., 2013; Garofalo et al., 2017). Therefore, the aim of the present study was to elucidate the bacteria and yeast species occurring in artisan Gioddu samples collected from three Sardinian producers by combining the results of viable counting on selective culture media and high-throughput sequencing. Physico-chemical parameters of Gioddu were also evaluated.

\section{Materials and methods}

\subsection{Gioddu production}

The Gioddu samples analyzed in the present study were collected from three artisanal producers located in the Sardinia Region. For each producer (producer A, producer B and producer C), three different production batches (batch 1, batch 2 and batch 3), realized between March and May 2019, were analyzed. The production of Gioddu was carried out in accordance with local tradition using ovine milk from daily milking. Briefly, ovine milk was collected approximately after 2 hours of milking, strained, and boiled for about 7 min. The milk was then cooled down to $30{ }^{\circ} \mathrm{C}$ and inoculated via back-slopping using $2 \%$ of a Gioddu manufacture of the previous day. During the $12 \mathrm{~h}$ fermentation, the temperature of $30{ }^{\circ} \mathrm{C}$ was maintained and the final products were stored at $5{ }^{\circ} \mathrm{C}$. For each sample, $100 \mathrm{~g}$ were collected immediately after the storage at $5{ }^{\circ} \mathrm{C}$. No commercial starter cultures were added to ovine milk prior to coagulation. Gioddu samples were produced in accordance with Good Hygiene Practices (GHP), although the artisanal dairy plants involved in the study showed some limitations due to their reduced production capacities.

\subsection{Determination of $p H$}


$\mathrm{pH}$ values of the Gioddu samples were measured by $\mathrm{pH}$ meter equipped with a solid HI2031 electrode (Hanna Instrument, Padova, Italy). For each sample, the measurements were performed in duplicate and the results were expressed as mean value \pm standard deviation.

\subsection{Viable counting}

One $\mathrm{mL}$ of each Gioddu sample was added with $9 \mathrm{~mL}$ of a sterile peptone water $(0.1 \%$ peptone, w/v) and homogenized by Stomacher 400 Circulator apparatus (VWR International PBI, Milan, Italy) at $260 \mathrm{rpm}$ for 3 min. The homogenates (dilution $10^{-1}$ ) were additionally ten-fold diluted and subjected to viable counts of lactic acid bacteria (LAB) (lactobacilli and lactococci), total and non-Saccharomyces yeasts. The enumeration of lactobacilli and lactococci was performed on de Man Rogosa and Sharpe (MRS) Agar (WVR, International, Leuven, Belgium) and M17 agar (Merck $\mathrm{KGaA}$, Darmstadt, Germany), respectively, using pour plate method. The agar plates were incubated at $37^{\circ} \mathrm{C}$ under anaerobic conditions (Gas-Pack system, Oxoid). Both growth media were supplemented with $250 \mathrm{mg} / \mathrm{L}$ of cycloheximide to inhibit yeast growth.

Total viable yeasts were enumerated on WL-nutrient agar (Oxoid) and non-Saccharomyces yeasts on Lysine agar (Oxoid) after incubation at $25^{\circ} \mathrm{C}$ for $72 \mathrm{~h}$. Both media were supplemented with $100 \mathrm{mg} / \mathrm{L}$ of chloramphenicol to inhibit the bacterial growth. The results were expressed as colony forming units (CFU) per $\mathrm{mL}$ of sample \pm standard deviations.

\subsection{DNA extraction, library preparation, and sequencing.}

Total DNA was extracted from the pellet of $1 \mathrm{ml}$ of the first decimal dilution prepared for the viable counts by using E.Z.N.A. soil DNA kit (Omega bio-tek, Norcross, GA, USA) following the manufacturer's instructions.

Microbiota were studied by amplifying the V3 and V4 region of the 16S rRNA using primers and condition described by Klindworth et al. (2013). Mycobiota were evaluated by amplifying the D1 domain of the 26S using primers and condition described by Mota-Gutierrez et al. (2019). Library preparation was performed according to the illumina metagenomic procedure. Sequencing was performed by MiSeq instrument (Illumina) with V3 chemistry and generated 250-bp paired-end reads, following the producer's instructions.

\subsection{Bioinformatics}


After sequencing reads were assembled, quality filtered and processed by using the QIIME 1.9.0 software (Caporaso et al., 2010), and the pipeline described by Ferrocino et al. (2017) (for 16S) and from Mota-Gutierrez et al. (2019) for the 26S. Centroids sequences of each cluster were manually check by Basic Local Alignment Search Tool (BLAST) to confirm the taxonomic assignment. QIIME was used to rarefy the operational taxonomic unit (OTU) table at the lowest number of sequences per sample and to build the OTU table. The OTU table displays the higher taxonomy resolution reached when the taxonomy assignment was not able to reach the species level, genus or family name was displayed.

The 16S and the 26S sequences are available at the Sequence Read Archive of the NCBI (SRA accession number SRP217105).

\subsection{Color measurement}

Chroma Meter CR-200 (Minolta, Japan) was used to define colorimetric profile of Gioddu samples determining lightness (L), redness-greenness ( $\mathrm{a}^{*}:$ + red; - green), yellowness-blueness $\left(\mathrm{b}^{*}:\right.$ + yellow; - blue) coordinates according to CIELab color space system, using a D65 light source. Moreover, the chromaticity of Gioddu samples was characterized calculating Chroma (C) and Whiteness Indexes (WI) with the following equation: $\sqrt{ }\left(\mathrm{a}^{2}+\mathrm{b}^{*^{2}}\right)$ and 100 $\sqrt{ }(100-\mathrm{L})^{2}+\mathrm{a}^{*^{2}}+\mathrm{b}^{*^{2}}$, respectively. The colorimetric readings were performed in triplicate for each Gioddu sample. Ultra-High Temperature (U.H.T.) goat milk was used as control.

\subsection{Statistical analysis}

The one-way analysis of variance (ANOVA) of colorimetric parameters was performed including Gioddu Producer (GP) as main effect. The GP had three levels: producer A, producer B, and producer C. The Tukey-Kramer test $(P \leq$ 0.05) was carried out to detect differences through multiple mean comparisons. The statistical analysis was performed using JMP software (version 11.0). In addition, $\mathrm{pH}$ and bacterial count data collected were subjected to one-way ANOVA using JMP software (version 11.0), and differences were considered non-significant at $P<0.05$. As a measure of the association between microbiota and mycobiota, the Spearman's rank correlation coefficient was obtained through the function psych and plotted through the corrplot package of R (FDR < 0.05).

\section{Results}

\subsection{Determination of $p H$}


The results of $\mathrm{pH}$ values detected in the analyzed Gioddu samples are reported in Table 1. In more detail, $\mathrm{pH}$ values of

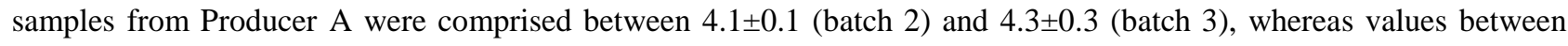
$3.9 \pm 0.1$ (batch 1) and 4.0 \pm 0.1 (batch 2) were detected in samples from Producer B. Samples from Producer C showed $\mathrm{pH}$ values that ranged between $3.5 \pm 0.3$ (batch 2) and 4.0 \pm 0.1 (batch 1). Producer A showed significantly higher overall $\mathrm{pH}$ mean value, whereas no significant differences were detected between overall $\mathrm{pH}$ mean values of samples from Producer B and Producer C.

\subsection{Viable counting}

The results of viable counts are reported in Table 1. In more detail, for samples from Producer A, counts of presumptive lactococci ranged between $4.9 \pm 0.1$ (batch 1) and 5.7 \pm 1.3 (batch 2) $\log \mathrm{cfu} \mathrm{mL}^{-1}$, whereas for samples from Producer B,

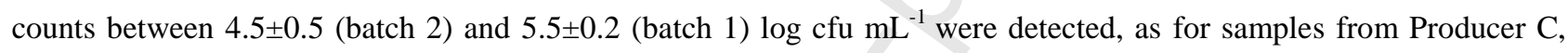
values ranged between $4.5 \pm 0.7$ (batch 1) and 4.7 \pm 0.3 (batch 3 ) $\log$ cfu $\mathrm{mL}^{-1}$. Producer A showed significantly highest overall mean value, whereas no significant differences were detected between overall mean values of Producer B and Producer C.

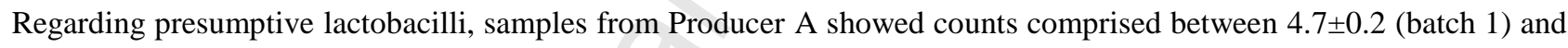

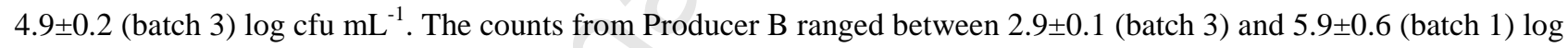
cfu $\mathrm{mL}^{-1}$, whereas samples from Producer C showed viable counts between 5.1 \pm 0.8 (batch 1) and 6.5 \pm 0.2 (batch 2) log cfu $\mathrm{mL}^{-1}$. Producer $\mathrm{C}$ showed significantly highest overall mean value, whereas no significant differences were detected between overall mean values of Producer A and Producer B.

As for total yeasts, values comprised between 5.6 \pm 0.2 (batch 3) and $6.3 \pm 0.1$ (batch 1) $\log \mathrm{cfu} \mathrm{mL}^{-1}$ were detected in samples from Producer A, whereas, in samples from Producer B, yeasts counts ranged between 6.9 \pm 0.1 (batch 3) and $7.3 \pm 0.1$ (batch 2) $\log$ cfu $\mathrm{mL}^{-1}$. Finally, values between $7.3 \pm 0.1$ and $8.4 \pm 0.1 \log$ cfu $\mathrm{mL}^{-1}$ were detected in samples from Producer C, this latter showing significantly highest overall mean value and Producer A the lowest.

Finally, non-Saccharomyces yeasts detected in samples from Producer A showed counts comprised between $5.6 \pm 0.1$ (batch 3) and 6.5 \pm 0.2 (batch 1) $\log \mathrm{cfu} \mathrm{mL}^{-1}$. Counts from Producer B ranged between $6.7 \pm 0.1$ (batch 1) and $7.3 \pm 0.3$ (batch 2) $\log$ cfu $\mathrm{mL}^{-1}$, whereas samples from Producer C showed counts between 7.2 \pm 0.1 (batch 1) and 8.1 \pm 0.1 (batch 2) $\log \mathrm{cfu} \mathrm{mL}^{-1}$. Producer $\mathrm{C}$ showed significantly highest overall mean value, whereas overall mean values of Producer A were the lowest. 


\subsection{Microbiota composition}

The total number of paired sequences obtained from the samples reached 336,855 raw reads. After quality filtering, a total of 237,722 reads were used, with an average value of $26,413 \pm 7,239$ reads/sample, and a mean sequence length of 465 bp. Alpha diversity index showed a satisfactory coverage for all samples (> 98\%) however it did not show different level of complexity based on the producers.

A simple microbiota composition was observed (Figure 1) with the dominance of Lactobacillus delbrueckii (higher than $85 \%$ in all the samples), while Streptococcus thermophilus was observed only in Producer A (14\% of the relative abundance) and Producer C (7\%). Taking into the account the minor microbial composition it was possible to observed the presence of Lactobacillus kefiri and Lactococcus lactis only in producer B and producer C (2.7 and $0.05 \%$ for the first one and $2 \%$ and $2.4 \%$ for the second ones respectively). Pseudomonas fragi was only detected in Producer B samples (1.4\% of the relative abundance).

\subsection{Mycobiota composition}

The total number of paired sequences obtained from the samples reached 577,662 raw reads. After quality filtering, a total of 509,845 reads were used, with an average value of 56,649 $\pm 31,359$ reads/sample, and a mean sequence length of $366 \mathrm{bp}$. Alpha diversity index showed a satisfactory coverage for all samples (> 99\%) however it did not show different level of complexity based on the producers.

Taking into the account the mycobiota composition at the highest taxonomic level (Figure 2) we can observe that samples from producer $\mathrm{B}$ and producer $\mathrm{C}$ has a higest degree of similarity characterizad by the predominance of Kluyveromyces marxianus ( 83 and $52 \%$ of the relative abundance in producer B and producer C respectively), Galactomyces candidum (11 and 34\%) and by the presence of Geotrichum galactomyces (4 and $12 \%$ in producer B and producer C respectively). Samples from producer A showed a high presence of Pichia cactophila (45\%), Glomus hyderabadensis $(16 \%)$ and Saccharomyces cerevisiae $(7 \%)$. The presence of several minor taxa belonging to Alternaria, Cladosporium and Aerobasidium was also observed.

\subsection{Correlations between microbiota and mycobiota profile}

Plotting the correlation between the microbiota and mycobiota (Figure 3, FDR $<0.05$ ), it was observed that the presence of $L$. delbrueckii exclude the presence of Alternaria tenuissima and Aerobasidium while the presence of the minor lactic 
acid bacteria (L. lactis and L. zeae) were associated with the prensence of Galactomyces candidum and Geotrichum galactomyces.

\subsection{Color measurement}

Results of color measurements carried out on Gioddu samples are reported in Supplementary Table 1. Ultra-High Temperature (U.H.T.) goat milk, used as control, showed the following colorimetric profile: L 90.52 \pm 0.01 ; $\mathrm{a}^{*}$ 7.68 $\pm 0.02 ; b^{*} 9.63 \pm 0.01 ; \mathrm{C} 12.83 \pm 0.90 ;$ WI $84.46 \pm 0.01$. ANOVA results, reported in Supplementary Table 1, showed significant difference between producers only for Lightness (L) parameter. Goat milk, used as a reference control, resulted with a higher Lightness $(\mathrm{L})$, redness $\left(\mathrm{a}^{*}\right)$ and WI compared to the three different dairy products. Gioddu made by Producer B and Producer C highlighted significantly higher mean values for L than the fermented dairy products manufactured by the Producer A.

\section{Discussion}

Sardinia inhabitants live in a geographical hot spot of exceptional longevity known as the "Longevity Blue Zone" (Pes et al., 2015). As reviewed by Pes et al. (2015) it is likely that, besides genetically predisposition, such an enviable status could be based on the availability of high-quality foods including traditional fermented products of milk-origin. Indeed, it is known that dairy fermented products are natural carriers of beneficial microorganisms (and their metabolites) with potential health benefits for the consumers (Şanlier et al., 2019).

Regarding $\mathrm{pH}$, the detected values were in accordance with those reported by Maoloni et al. (2019) in Gioddu samples; to the authors' knowledge no other studies reporting Gioddu $\mathrm{pH}$ values are available in the scientific literature for further comparison of data. The detected values agreed with those reported for sheep milk traditionally fermented at $37^{\circ} \mathrm{C}$ that showed $\mathrm{pH}$ values of 3.99-3.73 (Nadelman et al., 2017); the detected values were also in accordance with $\mathrm{pH}$ values reported for Dahi, a traditional fermented milk produced in Bangladesh, that showed $\mathrm{pH}$ values of 3.9-4.0 (Nahidul-Islam et al., 2018). Gioddu $\mathrm{pH}$ values were lower than those reported for ovine milk kefir that is usually fermented to $\mathrm{pH}$ 4.6-4.7 (Tamime et al., 2011). The overall low $\mathrm{pH}$ values detected in the analyzed Gioddu samples attested the strong acidifying activity carried out by lactic acid bacteria along fermentation.

Regarding viable counts, the occurrence of both presumptive lactococci and lactobacilli was in accordance with the results reported by Arrizza et al. (1983) on the same dairy product, where both these two groups of lactic acid bacteria were concurrently detected. Lactic acid bacteria represent the most extensively studied microorganisms for milk 
fermentation. Species belonging to this group are well-adapted to the milk environment where they produce organic acids (e.g. lactic and/or acetic acid) and secondary metabolites with potential antimicrobial and/or bioactive properties (Widyastuti et al., 2014). The counts of lactic acid bacteria detected in the present study were generally lower than those reported for fermented milks by other authors, where average counts usually attested at $>8 \log \mathrm{cfu} \mathrm{mL}^{-1}$ (Surono and Hosono, 2011). Interestingly, the relatively low lactic acid bacteria counts did not reflect in the low pH values (3.804.32) detected in the analyzed Gioddu samples at the end of fermentation, thus suggesting that among the detected species, strong acidifier were present, although at relatively low cell numbers. It is noteworthy that, regarding lactic acid bacteria, there are no growth media able to sufficiently select for the growth of the sole lactococci or lactobacilli, thus limiting the information obtained by classical methods. Hence, the use of culture-independent methods in combination with agar media appears particularly convenient (Vera et al., 2009).

As for the occurrence of eumycetes, to the authors' knowledge no previous data reporting the counts of yeast in Gioddu are available in the scientific literature for further comparison of data. Interestingly, the counts of total eumycetes (including Saccharomyces species) and non-Saccharomyces yeast were almost overlapping, thus confirming the results of metagenomic sequencing where Saccharomyces species were minority. The counts of yeasts in the analyzed Gioddu samples were almost in accordance with those reported by Kebede et al. (2007) in Sethemi, a South African spontaneously fermented milk, where counts of approximately $6 \log \mathrm{cfu} \mathrm{mL}^{-1}$ were detected. Yeast counts detected in Gioddu were also comparable with those reported by Kim et al. (2018a) and Guzel-Seydim et al. (2005) in milk kefir beverage that showed values of $6 \log \mathrm{cfu} \mathrm{mL}^{-1}$, thus suggesting similarities between Gioddu and this well-known health-promoting beverage, although the relative proportion of each microbial group should also be considered.

To the authors' knowledge the sole recent study dealing with the microbial diversity of Gioddu reported the presence of major taxa detected in samples obtained from two producers located in Sardinia (Maoloni et al., 2020). Although the study by Maoloni et al. (2020) shed a first light on the occurrence of both bacterial and fungal species, neither data on the relative abundances of the detected microorganisms nor minority species were reported. Hence, the metataxonomic approach applied in the present allowed major and minor taxa to be detected for the first time. In more detail, $L$. delbrueckii was detected as dominant species in all the analyzed samples. The occurrence of this lactic acid bacterium species has already been reported by Maoloni et al. (2019) in Gioddu samples analyzed via PCR-DGGE. The presence of this species has recently been reported by Jiang et al. (2020) in traditional fermented yak milk where L. delbrueckii was detected with relative abundance up to $99 \%$. Moreover, L. delbrueckii was also detected by Raveschot et al. (2020) as part of the major microbiota occurring in Mongolian traditional dairy products. The species L. delbrueckii includes lactobacilli that produces the $\mathrm{D}(-)$ isomer of lactic acid from lactose or from other carbohydrates. This milk-adapted species contributes to characterize the aroma of fermented milks due to the production of secondary compounds 
including acetaldehyde. As reported by Rizzello and De Angelis (2016), L. delbrueckii produces exopolysaccharides and bacteriocins that could influence the nutritional, safety and rheological aspects of the final product. Interestingly, Tang et al. (2020) recently reported that exopolysaccharides produced by L. delbruecckii ssp. bulgaricus could also exert prebiotic activity, although the functionality of these compounds should be confirmed through in vivo studies.

S. thermophilus has been detected in samples from Producer A and Producer C, thus suggesting the occurrence of a yogurt-like protocooperation between $S$. thermophilus and L. delbrueckii. S. thermophilus is a thermophilic aerotolerant-anaerobe bacterium with an optimal growth temperature of $42{ }^{\circ} \mathrm{C}$. In fermented milks, S. thermophilus is responsible for the production of lactic acid, together with secondary products as acetaldehyde and diacetyl that characterize the aroma and texture of the end products (Uriot et al., 2017). During lactic acid fermentation, the production of formate and $\mathrm{CO}_{2}$ by $S$. thermophilus stimulates L. bulgaricus growth that, in turn, releases peptides and amino acids from milk proteins, thus improving the growth of S. thermophilus (Sieuwerts et al., 2008). The presence of S. thermophilus in Gioddu has already been reported by Arrizza et al. (1983), although such lactic acid bacterium was not constantly detected in the core microbiota.

Of note the presence of $L$. kefiri in all the samples from the 3 batches collected from both producer B and Producer C. To the authors' knowledge, L. kefiri has usually been associated with kefir beverage, being part of the dominant microbiota of such health-promoting fermented milk (Garofalo et al., 2015; Slattery et al., 2019). Indeed, as reported by Sharifi et al. (2017) the consumption of milk kefir could exert antibacterial, antifungal, anti-allergic and antiinflammatory effects. Moreover, bioactive compounds produced by kefir microbiota as polysaccharides and peptides could inhibit proliferation of colorectal, breast and lung tumor cells (Sharifi et al., 2017). In kefir beverage, L. kefiri, together with L. kefiranofaciens, L. kefirgranum, L. parakefiri, releases exopolysaccharides with potential antioxidant, antitumor, antimicrobial, and immunomodulating properties (Prado et al., 2015), such exopolysaccharides (EPS) production is boosted by the complex symbiosis with yeasts that occur in kefir beverage. As reviewed by Slattery et al. (2019), L. kefiri strains could exert inhibitory effect on the growth of a wide range of human foodborne pathogens as Pseudomonas aeruginosa, Salmonella Enteritidis, Listeria monocytogenes, Bacillus cereus, Staphylococcus aureus, and Cronobacter sakazakii, this latter with particular risk to infants (Kim et al., 2018b). Moreover, a significant in vitro and in vivo cholesterol reducing activity was also reported for L. kefiri strain DH5 by Kim et al. (2017). Based on such evidences, it could be supposed that analogous activities of $L$. kefiri might be exerted by strains detected in the microbiota of Gioddu, although further research is needed to verify viability and EPS production in the analyzed samples. In addition to this, it is also essential to isolate and identify this microorganism from Gioddu. Although found with low frequencies, the detection of L. kefiri in Gioddu represents an absolute novelty and suggests that this fermented milk could be the source of still unknown beneficial effects on the health of consumers. 
As for L. lactis, detected with low abundances in samples from Producer B and Producer C, the presence of this lactic acid bacteria has already been reported in fermented milks (including buttermilk and sour cream) by different authors (Cavanagh et al., 2015; McNulty et al., 2011; Yang et al., 2013; Zhang et al., 2019). L. lactis, that represents one of the key lactic acid bacteria species in the dairy industry, produces lactic acid from lactose and flavour compounds from milk-proteins proteolysis (Cavanagh et al., 2015). Moreover, it is responsible for the production of EPS, these latter strongly related with texture development (van Hylckama Vlieg et al., 2006). Interestingly, a protocooperation between L. lactis and Kluyveromyces lactis in Lben product, a traditional Moroccan fermented milk, has been reported (Mangia et al., 2014)

Analogously to milk kefir, populations of eumycetes were detected in all the analyzed samples. In more detail, $K$. marxianus constituted the core mycobiota of samples from Producer B and Producer C, and a small fraction of yeasts detected in samples from Producer A. The detection of such yeast species is in accordance with preliminary studies carried out by Maoloni et al. (2019) in Gioddu samples through PCR-DGGE. Moreover, K. marxianus strains with potential probiotic features have recently been isolated by Fadda et al. (2017) from Fiore Sardo, a typical Sardinian hard cheese. K. marxianus has also been detected in homemade Chinese koumiss (Ni et al., 2007), in different French cheeses produced with raw milk (Callon et al., 2006), in African artisanal yoghurt and in traditionally fermented milks (Maïworé et al., 2019). K. marxianus is a dairy yeast that represents a sister species to Kluyveromyces lactis and is phylogenetically related to $S$. cerevisiae (Lane and Morrissey, 2010). K. marxianus is capable to assimilate lactose through $\beta$-galactosidase that hydrolyses this sugar to glucose and galactose, thus using these sugars as carbon source (Lane and Morrissey, 2010). This probiotic yeast could decrease cholesterol level, exert antifungal, antibacterial, antiinflammatory activity producing pro-inflammatory cytokines, thus reducing local and systemic inflammations (Pacini and Ruggiero, 2017; Şanlidere Aloğlu et al., 2016; Xie et al., 2015). Moreover, Rahbar Saadat et al. (2020) recently described the inhibitory role of the EPSs produced by $K$. marxianus on colorectal cancer.

As for G. candidum, such filamentous yeast-like fungus, that represents the teleomorphic state of Geotrichum candidum, has already been detected in Gioddu by Maoloni et al. (2019) through PCR-DGGE. G. candidum has recently been isolated by Maïworé et al. (2019) in African fermented milks where it predominated among the detected mycobiota. Interestingly, species belonging to the genus Galactomyces were recenlty detected by Araújo-Rodrigues et al. (2019) in Serpa PDO cheese, a raw ewes' milk cheese coagulated with extracts of Cynara cardunculus L., and in traditional fried cottage cheese (Grygier et al., 2020). It is noteworthy that members of the genus Galactomyces showed probiotic potential (Oliveira et al., 2017) as well as the capability to release bioactive peptides (e.g. angiotensinconverting enzyme inhibitory peptides) from milk proteins (Ahtesh et al., 2018). 
Regarding G. galactomyces, to the authors' knowledge no previous reports on the presence of such species in fermented milks or cheeses are available in the scientific literature for further comparison of data. To the Geotrichum species belongs acid-tolerant yeast-like fungi that are commonly detected in many mold-ripened, smear-ripened, and acidcoagulated cheeses (Eliskases-Lechner et al., 2011). Species belonging to the genus Geotrichum (e.g. Geotrichum candidum) have already been detected in Armada, a traditional Spanish cheese from goat milk, showing proteolytic and/or lipolytic capacity, thus conferring a strong "goat aroma" to the end product (Sacristán et al., 2012).

Pichia cactophila stronlgy characterized the mycobiota of Gioddu samples collected from Producer A. The presence of such yeast species in Gioddu has already been reported by Maoloni et al. (2019), moreover, strains of P. cactophila have been isolated by Aponte et al. (2010) in Mozzarella cheese produced with water buffalo milk. Pichia species have also been detected in artisanal Fiore Sardo cheese (Fadda et al., 2004) and in African artisanal yoghurts and traditional fermented milks (Maïworé et al., 2019), thus confirming the adaptation of such yeast genus to the dairy environment. Notwithstanding, the detection of $P$. cactophila in dairy products is rare, being this yeast commonly associated with necrotic stems of cacti (Moraes et al., 2005). Hence, it is likely that the occurrence of $P$. cactophila in the analyzed samples could be derived from environmental contamination.

Glomus hyderabadensis was detected in samples from Producer A and Producer B. To the authors' knowledge, this study reports the first detection of G. hyderabadensis in Gioddu and more generally in dairy products. This mycorrhizal fungus is commonly associated with rhizosphere soils; no reports on the occurrence of Glomus species in the food environment are actually available in the scientific literature (Rani et al., 2004). It is likely that the occurence of $G$. hyderabadensis in Gioddu could be related to environmental contamination of the dairy environment.

Finally, S. cerevisiae was detected in samples from producer A and, at very low frequencies, in samples from Producer B. The presence of such a yeast species has already been reported by several authors in milk kefir grains (Diosma et al., 2014; Gao et al., 2012; Garofalo et al., 2015; Zhou et al., 2009). Although unable to ferment lactose, S. cerevisiae is able to ferment galactose and could advantage by the presence of concurrent microbial species that release such a sugar through $\beta$-galactosidase activity. Moreover, S. cerevisiae can grow on lactate produced by lactic acid bacteria, as already described in kefir (Sieuwerts et al., 2018), thus explaining its presence in the analyzed Gioddu samples.

Regarding colorimetric parameters $\left(\mathrm{L}, \mathrm{a}^{*}, \mathrm{~b}^{*}\right)$ of Gioddu, the WI, expressing the preferences of consumers for white colors, is frequently used for the evaluation of many dairy products (Ghasemlou et al., 2011; Gul et al., 2018) since it is a synthetic expression of lightness perception and color coordinates into a single term (Pathare et al., 2013). However, as referred by Vargas et al. (2008), the WI can be affected by several physical-chemical parameters of milk as fat globules dimension, casein ratio, and casein micelles aggregations in the end product. Therefore, the mean values 
observed in the present study resulted very uniform and could be affected by the properties of the raw milk used to obtain Gioddu.

\section{Conclusions}

Based on the results of the metataxonomic approach, applied for the first time to Gioddu, the analyzed samples were characterized by a complex (kefir-like) microbiota of bacteria and yeasts where previously undetected species were found. Specifically, L. delbrueckii was detected at very high levels in all the samples, thus representing the key species in Gioddu fermentation together with S. thermophilus, whose presence suggested the establishment of a yogurt-like protocooperation. Unexpectedly, samples from two out of the three producers revealed the presence of $L$. kefiri in all the three analyzed batches, thus representing an absolute novelty and suggesting the presence of bioactive compounds (e.g. EPS) similar with those present in milk kefir beverage. Eumycetes population, studied for the first time in this fermented milk product, revealed a more complex mycobiota where potentially probiotic species, including $K$. marxianus, were detected. The data overall collected opened new research horizons aimed at discovering the presence in Gioddu of probiotic cultures that, through isolation, could be exploited in other fermented food products. Moreover, the presence of bioactive compounds (e.g. EPS, angiotensin-converting enzyme inhibitory peptides, antimicrobial compounds, etc.) with potential health-benefits for the consumers can also be hypothesized. Further research is needed to establish the stability of the microbial consortium throughout the back-slopping process.

Of note, the presence of Pseudomonas and eumycetes as P. cactophila, G. hyderabadensis, Alternaria, Cladosporium and Aerobasidium suggested the need for an improvement of hygiene practices during Gioddu manufacturing.

\section{Acknowledgments}

The authors wish to thank the farmers that kindly provided Gioddu samples.

\section{Conflict of interest}

The authors declare that they have no conflict of interest.

\section{References}


Ahtesh, F.B., Stojanovska, L., Apostolopoulos, V., 2018. Anti-hypertensive peptides released from milk proteins by probiotics. Maturitas 115, 103-109. https://doi.org/10.1016/j.maturitas.2018.06.016

Aponte, M., Pepe, O., Blaiotta, G., 2010. Identification and technological characterization of yeast strains isolated from samples of water buffalo Mozzarella cheese. J. Dairy Sci. 93 (6), 2358-2361. https://doi.org/10.3168/jds.20092948

Araújo-Rodrigues, H., Tavaria, F.K., dos Santos, M.T.P.G., Alvarenga, N., Pintado, M.M., 2019. A review on microbiological and technological aspects of Serpa PDO cheese: an ovine raw milk cheese. Int. Dairy J. 100, 104561. https://doi.org/10.1016/j.idairyj.2019.104561

Arrizza, S., Ledda, A., Sarra, P.G., Dellaglio, F., 1983. Identification of lactic acid bacteria in "Gioddu". Scienza e Tecnica Lattiero-Casearia. 34 (2), 87-102.

Aryana, K.J., Olson, D.W., 2017. A 100-Year Review: Yogurt and other cultured dairy products. J. Dairy Sci. 100 (12), 9987-10013. https://doi.org/10.3168/jds.2017-12981

Callon, C., Delbès, C., Duthoit, F., Montel, M.C., 2006. Application of SSCP-PCR fingerprinting to profile the yeast community in raw milk Salers cheeses. Syst. Appl. Microbiol. $29 \quad$ (2), 172-180. https://doi.org/10.1016/j.syapm.2005.07.008

Caporaso, J.G., Kuczynski, J., Stombaugh, J., Bittinger, K., Bushman, F.D., Costello, E.K., Fierer, N., Peña, A.G., Goodrich, J.K., Gordon, J.I., Huttley, G.A., Kelley, S.T., Knights, D., Koenig, J.E., Ley, R.E., Lozupone, C.A., McDonald, D., Muegge, B.D., Pirrung, M., Reeder, J., Sevinsky, J.R., Turnbaugh, P.J., Walters, W.A., Widmann, J., Yatsunenko, T., Zaneveld, J., Knight, R., 2010. QIIME allows analysis of high-throughput community sequencing data. Nat. Methods. 7, 335-336. https://doi.org/10.1038/nmeth.f.303

Cardinali, F., Osimani, A., Taccari, M., Milanović, V., Garofalo, C., Clementi, F., Polverigiani, S., Zitti, S., Raffaelli, N., Mozzon, M., Foligni, R., Franciosi, E., Tuohy, K., Aquilanti, A. 2017 Impact of thistle rennet from Carlina acanthifolia All. subsp. acanthifolia on bacterial diversity and dynamics of a specialty Italian raw ewes' milk cheese. Int. J. Food Microbiol. 255, 7-16. https://doi.org/10.1016/j.ijfoodmicro.2017.05.018

Cardinali, F., Taccari, M., Milanović, V., Osimani, A., Polverigiani, S., Garofalo, C., Foligni, R., Mozzon, M., Zitti, S., Raffaelli, N., Clementi, F., Aquilanti, L., 2016. Yeast and mold dynamics in Caciofiore della Sibilla cheese coagulated with an aqueous extract of Carlina acanthifolia All. Yeast 33, $403-414$. https://doi.org/10.1002/yea.3168

Cavanagh, D., Fitzgerald, G.F., McAuliffe, O., 2015. From field to fermentation: The origins of Lactococcus lactis and its domestication to the dairy environment. Food Microbiol. 47, 45-61. https://doi.org/10.1016/j.fm.2014.11.001 
Ceapa, C., Wopereis, H., Rezaïki, L., Kleerebezem, M., Knol, J., Oozeer, R., 2013. Influence of fermented milk products, prebiotics and probiotics on microbiota composition and health. Best Pract. Res. Clin. Gastroenterol. 27 (1), 139-155. https://doi.org/10.1016/j.bpg.2013.04.004

Cocolin, L., Alessandria, V., Dolci, P., Gorra, R., Rantsiou, K., 2013. Culture independent methods to assess the diversity and dynamics of microbiota during food fermentation. Int. J. Food Microbiol. 167, $29-43$. https://doi.org/10.1016/j.ijfoodmicro.2013.05.008

Diosma, G., Romanin, D.E., Rey-Burusco, M.F., Londero, A., Garrote, G.L., 2014. Yeasts from kefir grains: isolation, identification, and probiotic characterization. World J. Microbiol. Biotechnol. 30 (1), 43-53. https://doi.org/10.1007/s11274-013-1419-9

Eliskases-Lechner, F., Guéguen, M., Panoff, J.M., 2011. Yeasts and Molds. Geotrichum candidum. In Fuquay, J.W. (Ed.), Encyclopedia of Dairy Sciences, 2nd edition. Academic Press, San Diego, pp. 765-771. https://doi.org/10.1016/B978-0-12-374407-4.00365-4

Fadda, M.E., Mossa, V., Deplano, M., Pisano, M.B., Cosentino, S., 2017. In vitro screening of Kluyveromyces strains isolated from Fiore Sardo cheese for potential use as probiotics. LWT 75, 100-106. https://doi.org/10.1016/j.lwt.2016.08.020

Fadda, M.E., Mossa, V., Pisano, M.B., Deplano, M., Cosentino, S., 2004. Occurrence and characterization of yeasts isolated from artisanal Fiore Sardo cheese. Int. J. Food Microbiol. 95 (1), 51-59. https://doi.org/10.1016/j.ijfoodmicro.2004.02.001

Ferrocino., I., Bellio, A., Romano, A., Macori, G., Rantsiou, K., Decastelli, L., Cocolin, L., 2017. RNA-based amplicon sequencing reveals the microbiota development during ripening of artisanal vs. industrial Lard d'Arnad. Appl. Environ. Microbiol. 83 (16), e00983-17. https://doi.org/10.1128/AEM.00983-17

Gao, J., Gu, F., Abdella, N.H., Ruan, H., He, G., 2012. Investigation on culturable microflora in Tibetan kefir grains from different areas of China. J. Food Sci. 77 (8), M425-M433. https://doi.org/10.1111/j.17503841.2012.02805.x

Garofalo, C., Osimani, A., Milanović, V., Aquilanti, L., De Filippis, F., Stellato, G., Di Mauro, S., Turchetti, B., Buzzini, P., Ercolini, D., Clementi, F., 2015. Bacteria and yeast microbiota in milk kefir grains from different Italian regions. Food Microbiol. 49, 123-133. https://doi.org/10.1016/j.fm.2015.01.017

Garofalo, C., Bancalari, E., Milanović, V., Cardinali, F., Osimani, A., Sardaro, M.L.S., Bottari, B., Bernini, V., Aquilanti, L., Clementi, F., Neviani, E., Gatti, M., 2017. Study of the bacterial diversity of foods: PCR-DGGE versus LH-PCR. Int. J. Food Microbiol. 242, 24-36. https://doi.org/10.1016/j.ijfoodmicro.2016.11.008 
Ghasemlou, M., Khodaiyan, F., Oromiehie, A., Saeid Yarmand, M., 2011. Development and characterisation of a new biodegradable edible film made from kefiran, an exopolysaccharide obtained from kefir grains. Food Chem. 127, 1496-1502. https://doi.org/10.1016/j.foodchem.2011.02.003

Grygier, A., Myszka, K., Juzwa, W., Białas, W., Rudzińska, M., 2020. Galactomyces geotrichum mold isolated from a traditional fried cottage cheese produced omega-3 fatty acids. Int. J. Food Microbiol. 319, 108503. https://doi.org/10.1016/j.ijfoodmicro.2019.108503

Gul, O., Atalar, I., Mortas, M., Dervisoglu, M., 2018. Rheological, textural, colour and sensorial properties of kefir produced with buffalo milk using kefir grains and starter culture: A comparison with cows' milk kefir. Int. J. Dairy Technol. 71(1), 73-80. https://doi.org/10.1111/1471-0307.12503

Guzel-Seydim, Z., Wyffels, J.T., Seydim, A.C., Greene, A.K., 2005. Turkish kefir and kefir grains: microbial enumeration and electron microscopic observation. Int. J. Dairy Technol. 58 (1), 25-29. https://doi.org/10.1111/j.1471-0307.2005.00177.x

Italian Ministry of Agriculture and Forestry (G.U. Repubblica Italiana no. 168, 22/07/2015 Suppl. Ord. no. 43) Quindicesima revisione dell'elenco nazionale dei prodotti agroalimentari tradizionali.

Jiang, Y., Li, N., Wang, Q., Liu, Z., Lee, Y.-K., Liu, X., Zhao, J., Zhang, H., Chen, W., 2020. Microbial diversity and volatile profile of traditional fermented yak milk. J. Dairy Sci. 103 (1), 87-97. https://doi.org/10.3168/jds.201916753

Kebede, A., Viljoen, B. C., Gadaga, H., Narvhus, J. A., Lourens-Hattingh, A., 2007. The effect of incubation temperature on the survival and growth of yeasts in sethemi, South African naturally fermented milk. Food Technol. Biotechnol. 45(1), 21-26.

Kim, D.H., Jeong, D., Kang, I.B., Kim, H., Song, K.Y., Seo, K.H., 2017. Dual function of lactobacillus kefiri dh5 in preventing high-fat-diet-induced obesity: Direct reduction of cholesterol and upregulation of ppar-alpha in adipose tissue. Mol. Nutr. Food Res. 61 (11). https://doi.org/10.1002/mnfr.201700252

Kim, D.H., Jeong, D., Song, K.Y., Seo, K.H., 2018a. Comparison of traditional and backslopping methods for kefir fermentation based on physicochemical and microbiological characteristics. LWT 97, 503-507. https://doi.org/10.1016/j.lwt.2018.07.023

Kim, D.H., Jeong, D., Song, K.Y., Kang, I.B., Kim, H., Seo, K.H., 2018b. Culture supernatant produced by lactobacillus kefiri from kefir inhibits the growth of Cronobacter sakazakii. J. Dairy Res. 85, 98-103. https://doi.org/10.1017/S0022029917000802 
Klindworth, A., Pruesse, E., Schweer, T., Peplies, J., Quast, C., Horn, M., Glöckner, F.O., 2013. Evaluation of general 16S ribosomal RNA gene PCR primers for classical and next-generation sequencing-based diversity studies. Nucleic Acids Res. 41 (1) e1. https://doi.org/10.1093/nar/gks808

Lane, M.M., Morrissey, J.P., 2010. Kluyveromyces marxianus: a yeast emerging from its sister's shadow. Fungal Biol. Rev. 24 (1-2), 17-26. https://doi.org/10.1016/j.fbr.2010.01.001

Maïworé, J., Tatsadjieu Ngoune, L., Piro-Metayer, I., Montet, D., 2019. Identification of yeasts present in artisanal yoghurt and traditionally fermented milks consumed in the northern part of Cameroon. Sci. Afr. 6, e00159. https://doi.org/10.1016/j.sciaf.2019.e00159

Mangia, N.P., Garau, G., Murgia, M.A., Bennani, A., Deiana, P., 2014. Influence of autochthonous lactic acid bacteria and enzymatic yeast extracts on the microbiological, biochemical and sensorial properties of Lben generic products. J. Dairy Sci. 81 (2), 193-201. https://doi.org/10.1017/S0022029914000119

Maoloni, A., Milanović, V., Cardinali, F., Mangia, N.P., Murgia, M.A., Garofalo, C., Clementi, F., Osimani, A., Aquilanti, L., 2019. Bacterial and Fungal Communities of Gioddu as Revealed by PCR-DGGE Analysis. Indian J. Microbiol. https://doi.org/10.1007/s12088-019-00838-6

McNulty, N.P., Yatsunenko, T., Hsiao, A., Faith, J.J., Muegge, B.D., Goodman, A.L., Henrissat, B., Oozeer, R., CoolsPortier, S., Gobert, G., 2011. The impact of a consortium of fermented milk strains on the gut microbiome of gnotobiotic mice and monozygotic twins. Sci. Transl. Med. 3, 106 ra106. https://doi.org/10.1126/scitranslmed.3002701

Moraes, E.M., Rosa, C.A., Sene, F.M., 2005. Preliminary notes on yeasts associated with necrotic cactus stems from different localities in Brazil. Braz. J. Biol. 65 (2), 299-304. http://dx.doi.org/10.1590/S151969842005000200014

Mota-Gutierrez, J., Ferrocino, I., Rantsiou, K., Cocolin, L., 2019. Metataxonomic comparison between internal transcribed spacer and 26S ribosomal large subunit (LSU) rDNA gene. Int. J. Food Microbiol. 290, $132-140$. https://doi.org/10.1016/j.ijfoodmicro.2018.10.010

Nadelman, P., Frazão, J.V., Vieira, T.I., Balthazar, C.F., Andrade, M.M., Alexandria, A.K., Cruz, A.G., FonsecaGonçalves, A., Maia, L.C., 2017. The performance of probiotic fermented sheep milk and ice cream sheep milk in inhibiting enamel mineral loss. Food Res. Int. 97, 184-190. https://doi.org/10.1016/j.foodres.2017.03.051

Nahidul-Islam, S.M., Kuda, T., Takahashi, H., Kimura, B., 2018. Bacterial and fungal microbiota in traditional Bangladeshi fermented milk products analysed by culture-dependent and culture-independent methods. Food Res. Int. 111, 431-437. https://doi.org/10.1016/j.foodres.2018.05.048 
Ni, H.J., Bao, Q.H., Sun, T.S., Chen, X., Zhang, H.P., 2007. Identification and biodiversity of yeasts isolated from Koumiss in Xinjiang of China.Wei Sheng Wu Xue Bao 47 (4), 578-582.

Oliveira, T., Ramalhosa, E., Nunes, L., Pereira, J.A., Colla, E., Pereira, E.L., 2017. Probiotic potential of indigenous yeasts isolated during the fermentation of table olives from Northeast of Portugal. Innov. Food Sci. Emerg. Technol. 44, 167-172. https://doi.org/10.1016/j.ifset.2017.06.003

Ortu, S., Felis, G.E., Marzotto, M., Deriu, A., Molicotti, P., Sechi, L.A., Dellaglio, F., Zanetti, S., 2007. Identification and functional characterization of Lactobacillus strains isolated from milk and Gioddu, a traditional Sardinian fermented milk. Int. Dairy J. 17, 1312-1320. https://doi.org/10.1016/j.idairyj.2007.02.008

Pacini, S., Ruggiero, M., 2017. Description of a novel probiotic concept: implications for the modulation of the immune system. Am. J. Immunol. 13 (2), 107-113. https://doi.org/10.3844/ajisp.2017.107.113

Pathare, P.B., Opara, U.L., Al-Said, F.A.J., 2013. Colour Measurement and Analysis in Fresh and Processed Foods: A Review. Food Bioproc. Tech. 6 (1), 36-60. https://doi.org/10.1007/s11947-012-0867-9

Pes, G., Tolu, F., Dore, M. Errigo, A., Canelada, A., Poulain, M., 2015. Male longevity in Sardinia, a review of historical sources supporting a causal link with dietary factors. Eur. J. Clin. Nutr. 69, 411-418. https://doi.org/10.1038/ejcn.2014.230

Prado, M.R., Blandón, L.M., Vandenberghe, L.P., Rodrigues, C., Castro, G.R., Thomaz-Soccol, V., Soccol, C.R., 2015. Milk kefir: composition, microbial cultures, biological activities, and related products. Front Microbiol. 6:1177. https://doi.org/10.3389/fmicb.2015.01177

Rahbar Saadat, Y., Yari Khosroushahi, A., Movassaghpour, A.A., Talebi, M., Pourghassem Gargari, B., 2020. Modulatory role of exopolysaccharides of Kluyveromyces marxianus and Pichia kudriavzevii as probiotic yeasts from dairy products in human colon cancer cells. J. Funct. Foods 64, 103675. https://doi.org/10.1016/j.jff.2019.103675

Rahbar Saadat, Y., Yari Khosroushahi, A., Pourghassem Gargari, B., 2019. A comprehensive review of anticancer, immunomodulatory and health beneficial effects of the lactic acid bacteria exopolysaccharides. Carbohydr. Polym. 217, 79-89. https://doi.org/10.1016/j.carbpol.2019.04.025

Rani, S.S., Kunwar, I.K., Prasad, G.S., Manoharachary, C., 2004. Glomus hyderabadensis, a new species: its taxonomy and phylogenetic comparison with related species. Mycotaxon 89 (2), 245-253.

Raveschot, C., Cudennec, B., Deracinois, B., Frémont, M., Vaeremans, M., Dugersuren, J., Demberel, S., Drider, D., Dhulster, P., Coutte, F., Flahaut, C., 2020. Proteolytic activity of Lactobacillus strains isolated from Mongolian traditional dairy products: A multiparametric analysis. Food Chem. 304, 125415. https://doi.org/10.1016/j.foodchem.2019.125415 
Rizzello, C.G., De Angelis, M., 2016. Lactobacillus delbrueckii Group, Reference module in food science. Encyclopedia of Dairy Sciences. Elsevier, New York, pp 119-124.

Sacristán, N., González, L., Castro, J.M., Fresno, J.M., Tornadijo, M.E., 2012. Technological characterization of Geotrichum candidum strains isolated from a traditional Spanish goats' milk cheese. Food Microbiol. 30 (1), 260-266. https://doi.org/10.1016/j.fm.2011.10.003

Şanlidere Aloğlu, H., Demir Özer, E., Öner, Z., 2016. Assimilation of cholesterol and probiotic characterisation of yeast strains isolated from raw milk and fermented foods. Int. J. Dairy Technol. 69 (1), 63-70. https://doi.org/10.1111/1471-0307.12217

Şanlier, N., Gökcen, B.B., Sezgin, A.C., 2019. Health benefits of fermented foods. Crit. Rev. Food Sci. Nutr. 59 (3), 506-527. https://doi.org/10.1080/10408398.2017.1383355

Sharifi, M., Moridnia, A., Mortazavi, D., Salehi, M., Bagheri, M., Sheikhi, A., 2017. Kefir: a powerful probiotics with anticancer properties. Med. Oncol. 34(11), 183. https://doi.org/10.1007/s12032-017-1044-9

Sieuwerts, S., Bron, P.A., Smid, E.J., 2018. Mutually stimulating interactions between lactic acid bacteria and Saccharomyces cerevisiae in sourdough fermentation. LWT 90, 201-206. https://doi.org/10.1016/j.lwt.2017.12.022

Sieuwerts, S., de Bok, F.A.M., Hugenholtz, J., van Hylckama Vlieg, J.E.T., 2008. Unraveling microbial interactions in food fermentations: From classical to genomics approaches. Appl. Environ. Microbiol. 74(16), 4997-5007. https://doi.org/10.1128/AEM.00113-08

Slattery, C., Cotter, P.D., O'Toole, P.W. 2019. Analysis of Health Benefits Conferred by Lactobacillus Species from Kefir. Nutrients. 11(6), E1252. https://doi.org/10.3390/nu11061252

Surono, I.S., Hosono, A., 2011. Fermented milks. Types and standards of identity. In Fuquay, J.W. (Ed.), Encyclopedia of Dairy Sciences, 2nd edition. Academic Press, San Diego, pp. 470-476. https://doi.org/10.1016/B978-0-12374407-4.00180-1

Tamime, A.Y., 2002. Fermented milks: a historical food with modern applications-a review. Eur. J. Clin. Nutr. 56, Suppl 4, S2-S15. https://doi.org/10.1038/sj.ejcn.1601657

Tamime, A.Y., Wszolek, M., Božanić, R., Özer, B., 2011. Popular ovine and caprine fermented milks. Small Ruminant Res. 101 (1-3), 2-16. https://doi.org/10.1016/j.smallrumres.2011.09.021

Tang, W., Zhou, J., Xu, Q., Dong, M., Fan, X., Rui, X., Zhang, Q., Chen, X., Jiang, M., Wu, J., Li, W., 2020. In vitro digestion and fermentation of released exopolysaccharides (r-EPS) from Lactobacillus delbrueckii ssp. bulgaricus SRFM-1. Carbohydr. Polym. 230, 115593. https://doi.org/10.1016/j.carbpol.2019.115593 
Uriot, O., Denis, S., Junjua, M., Roussel, Y., Dary-Mourot, A., Blanquet-Diot, S., 2017. Streptococcus thermophilus: From yogurt starter to a new promising probiotic candidate? J. Funct. Foods. 37, $74-89$. https://doi.org/10.1016/j.jff.2017.07.038

van Hylckama Vlieg, J.E.T., Rademaker, J.L.W., Bachmann, H., Molenaar, D., Kelly, W.J., Siezen, R.J., 2006. Natural diversity and adaptive responses of Lactococcus lactis. Curr. Opin. Biotechnol. 17 (2), 183-190. https://doi.org/10.1016/j.copbio.2006.02.007

Vargas, M., Chafer, M., Albors, A., Chiralt, A., Gonzalez-Martınez, C., 2008. Physicochemical and sensory characteristics of yogurt produced from mixtures of cows' and goats' milk. Int. Dairy J. 18 (12), 1146-1152. https://doi.org/10.1016/j.idairyj.2008.06.007

Vera, A., Rigobello, V., Demarigny, Y., 2009. Comparative study of culture media used for sourdough lactobacilli. Food Microbiol. 26, 728-733. http://dx.doi.org/10.1016/j.fm.2009.07.010

Widyastuti, Y., Rohmatussolihat, R., Febrisiantosa, A., 2014. The role of lactic acid bacteria in milk fermentation. Food Nutr. Sci. 5, 435-442. http://dx.doi.org/10.4236/fns.2014.54051

Xie, Y., Zhang, H., Liu, H., Xiong, L., Gao, X., Jia, H., Lian, Z., Tong, N., Han, T., 2015. Hypocholesterolemic effects of Kluyveromyces marxianus M3 isolated from Tibetan mushrooms on diet-induced hypercholesterolemia in rat. Braz. J. Microbiol. 46 (2), 389-395. http://dx.doi.org/10.1590/S1517-838246220131278

Yang, X., Wang, Y., Huo, G., 2013. Complete Genome Sequence of Lactococcus lactis subsp. lactis KLDS4. 0325. Genome Announc. 1, e00962-e00913. https://doi.org/10.1128/genomeA.00962-13

Zhang, J.S., Corredig, M., Morales-Rayas, R., Hassan, A., Griffiths, M.W., LaPointe, G. 2019. Effect of fermented milk from Lactococcus lactis ssp. cremoris strain JFR1 on Salmonella invasion of intestinal epithelial cells. J. Dairy Sci. 102 (8), 6802-6819. https://doi.org/10.3168/jds.2018-15669

Zhou, J., Liu, X., Jiang, H., Dong, M., 2009. Analysis of the microflora in Tibetan kefir grains using denaturing gradient gel electrophoresis. Food Microbiol. 26 (8), 770-775. https://doi.org/10.1016/j.fm.2009.04.009 


\section{FIGURE LEGENDS}

Figure 1. Relative abundance of the microbiota detected in Gioddu samples. Only OTUs which showed an incidence above $0.2 \%$ in at least 2 samples are shown.

Figure 2. Relative abundance of the mycobiota detected in Gioddu samples. Only OTUs which showed an incidence above $0.5 \%$ in at least 2 samples are shown

Figure 3. Correlation plot showing Spearman's correlation between microbiota and mycobiota composition. Only significance associations are shown $($ FDR $<0.05)$. The intensity of the colors represents the degree of correlation, where the color blue represents a positive degree of correlation and red a negative correlation. 
Journal Pre-proof

Table 1. Viable counts $(\log \mathrm{cfu} / \mathrm{mL})$ and $\mathrm{pH}$ values of Gioddu samples collected from the three producers (A, B, and C).

\begin{tabular}{|c|c|c|c|c|c|c|c|c|c|c|c|c|}
\hline & \multicolumn{3}{|c|}{ Producer A } & & \multicolumn{3}{|c|}{ Producer B } & & \multicolumn{3}{|c|}{ Producer C } & \multirow[b]{2}{*}{$\begin{array}{l}\begin{array}{l}\text { Overall } \\
\text { mean }\end{array} \\
\end{array}$} \\
\hline & Batch 1 & Batch 2 & Batch 3 & $\begin{array}{l}\text { Overall } \\
\text { mean }\end{array}$ & Batch 1 & Batch 2 & Batch 3 & $\begin{array}{l}\text { Overall } \\
\text { mean }\end{array}$ & Batch 1 & Batch 2 & Batch 3 & \\
\hline $\begin{array}{l}\text { Presumptive } \\
\text { lactococci }\end{array}$ & $4.9 \pm 0.1$ & $5.7 \pm 1.3$ & $5.5 \pm 0.8$ & $5.4 \pm 0.83^{\mathrm{a}}$ & $5.5 \pm 0.2$ & $4.5 \pm 0.5$ & $4.9 \pm 0.6$ & $4.9 \pm 0.6^{b}$ & $4.5 \pm 0.7$ & $4.6 \pm 0.9$ & $4.7 \pm 0.3$ & $4.6 \pm 0.6^{b}$ \\
\hline $\begin{array}{l}\text { Presumptive } \\
\text { lactobacilli }\end{array}$ & $4.7 \pm 0.2$ & $4.6 \pm 0.8$ & $4.9 \pm 0.2$ & $4.8 \pm 0.48^{b}$ & $5.9 \pm 0.6$ & $5.4 \pm 0.1$ & $2.9 \pm 0.1$ & $4.7 \pm 1.4^{\mathrm{b}}$ & $5.1 \pm 0.8$ & $6.5 \pm 0.2$ & $5.8 \pm 0.7$ & $5.8 \pm 0.8^{\mathrm{a}}$ \\
\hline Total yeasts & $6.3 \pm 0.1$ & $5.8 \pm 0.2$ & $5.6 \pm 0.2$ & $5.9 \pm 0.40^{\mathrm{c}}$ & $6.8 \pm 0.1$ & $7.3 \pm 0.1$ & $6.9 \pm 0.1$ & $7.1 \pm 0.2^{b}$ & $7.3 \pm 0.1$ & $8.4 \pm 0.1$ & $7.8 \pm 0.2$ & $7.8 \pm 0.5^{\mathrm{a}}$ \\
\hline $\begin{array}{l}\text { Non- } \\
\text { Saccharomyces } \\
\text { yeasts }\end{array}$ & $6.5 \pm 0.2$ & $5.8 \pm 0.1$ & $5.6 \pm 0.1$ & $5.9 \pm 0.41^{\mathrm{c}}$ & $6.7 \pm 0.1$ & $7.3 \pm 0.3$ & $6.9 \pm 0.3$ & $6.9 \pm 0.2^{b}$ & $7.2 \pm 0.1$ & $8.1 \pm 0.1$ & $7.7 \pm 0.2$ & $7.7 \pm 0.1^{\mathrm{a}}$ \\
\hline $\mathrm{pH}$ & $4.3 \pm 0.1$ & $4.1 \pm 0.1$ & $4.3 \pm 0.3$ & $4.2 \pm 0.13^{\mathrm{a}}$ & $3.9 \pm 0.1$ & $4.0 \pm 0.1$ & $3.9 \pm 0.1$ & $3.9 \pm 0.1^{b}$ & $4.0 \pm 0.1$ & $3.5 \pm 0.3$ & $3.8 \pm 0.1$ & $3.8 \pm 0.1^{\mathrm{b}}$ \\
\hline
\end{tabular}

Means \pm standard deviations of triplicate independent experiments are shown.

Within each row, overall means with different superscript letters are significantly different $(P<0.05)$.

cfu, colony forming units. 


\section{Highlights}

Microbiota of Gioddu samples collected from three Sardinian producers was analyzed

Lactococci, lactobacilli, and non-Saccharomyces yeasts were detected

The dominance of Lactobacillus delbrueckii was highlighted in all the samples

The presence of Lactobacillus kefiri was revealed in the majority of samples

Kluyveromyces, Galactomyces, and Geotrichum constituted the core mycobiota 


\section{Producer A}

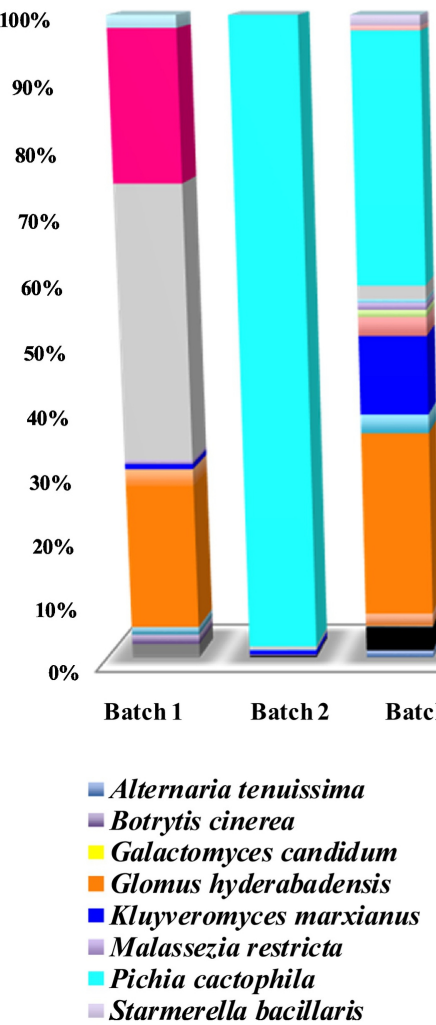

\section{Producer B}

\section{Producer C}

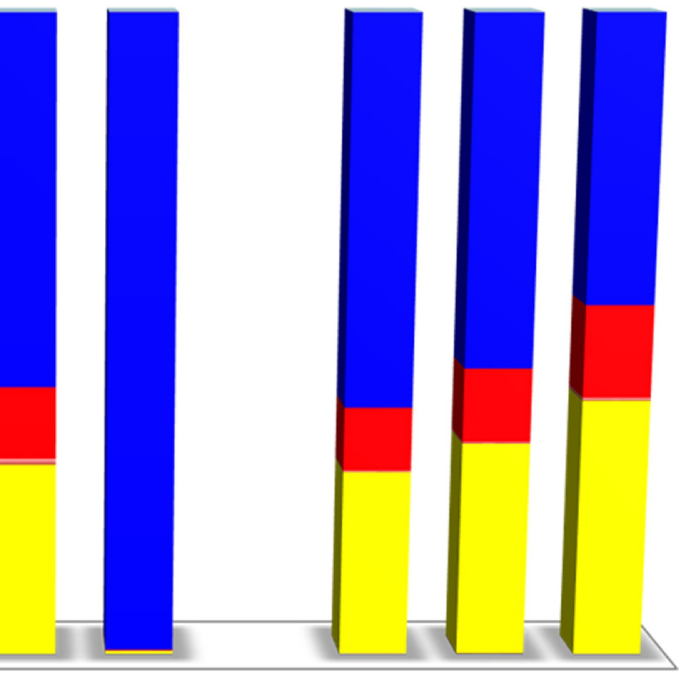



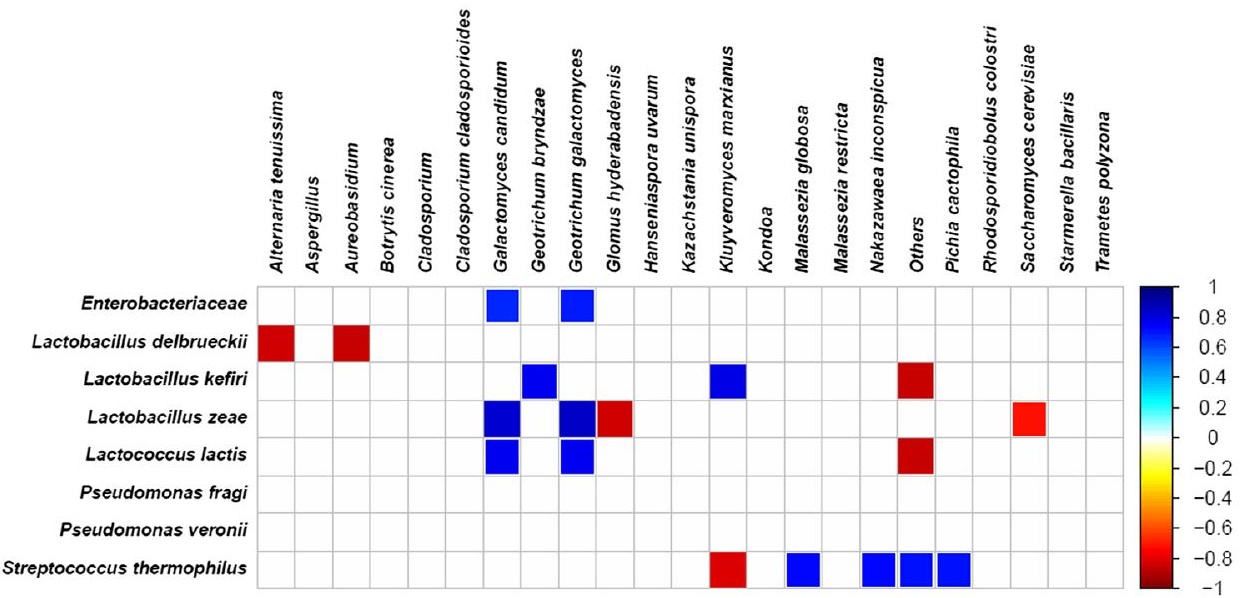